\title{
The relationship between visuospatial functions and executive functions of female Schizophrenia patients admitted to a psychiatric hospital
}

\author{
Maryam Foodeh ${ }^{1}$, Elham Foroozandeh ${ }^{2}$ \\ 1-Msc Student of Clinical Psychology, Department of Psychology, Naein Branch, Islamic Azad University, Naein, \\ Iran. \\ 2- Assistant Professor, Department of Psychology, Naein Branch, Islamic Azad University, Naein, Iran \\ (Corresponding Author). $\quad$ E-mail: elham_for@yahoo.com
}

Received: 29/05/2020 Accepted: 31/08/2020

\begin{abstract}
Introduction: Defective executive functions impair behavioral and emotional control in schizophrenia patients, and identification of its correlates can help design treatment protocols.

Aim: The present study aimed to investigate the relationship between visuospatial functions and executive functions of female patients with schizophrenia admitted to a psychiatric hospital.

Method: In this descriptive correlational study, the statistical population consisted of female patients with schizophrenia admitted to Najaf-Abad Modarres Psychiatric Hospital from September 23, to December 21, 2019, to receive medical treatment. To conduct this study, 50 individuals were selected using the purposive sampling technique based on inclusion criteria. The subjects were subjected to mini-mental state examination (MMSE) and clock drawing test (CDT). Data were analyzed using SPSS-24 by Pearson correlation and stepwise regression methods.
\end{abstract}

Results: Results indicated significant positive relationships between visuospatial functions in the first $(\mathrm{r}=0.414, \mathrm{p}<0.01)$ and second $(\mathrm{r}=0.552, \mathrm{p}<0.01)$ stages with executive functions of patients in the CDT. Among predictor variables, the visuospatial function in the second stage (beta coefficient $=0.524$ ) was a significant predictor of executive functions in schizophrenia patients $(\mathrm{p}<0.05)$.

Conclusion: It can be concluded that executive functions in patients with schizophrenia can be improved by providing cognitive rehabilitation interventions and timely and appropriate training to enhance their visuospatial function.

Keywords: Schizophrenia, Executive function, Visuospatial function

\footnotetext{
How to cite this article: Foodeh M, Foroozandeh E. The relationship between visuospatial functions and executive functions of female Schizophrenia patients admitted to a psychiatric hospital. Shenakht Journal of Psychology and Psychiatry. 2020; 7 (4): 13-27 .URL: http://shenakht.muk.ac.ir/article-1-875-en.pdf
}

Copyright $(92018$ the Author (s). Published by Kurdistan University of Medical Sciences. This is an open access article distributed under the terms of the Creative Commons Attribution-Non Commercial License 4.0 (CCBY-NC), where it is permissible to download, share, remix, transform, and buildup the work provided it is properly cited. The work cannot be used commercially without permission from the journal. 


\title{
رابطه عملكرد ديدارى -فضايى (ترسيمى) با عملكر دهاى اجرايى بيماران اسكيزوفرنياى زن بسترى در بيمارستان روانبزشكى
}

\author{
مريم فوده'، الهام فروزنده' \\ ا. كارشناسى ارشد روانشناسى بالينى، كروه روانشناسى، واحد نايين، دانشكاه آزاد اسلامى، نايين، ايران.
}

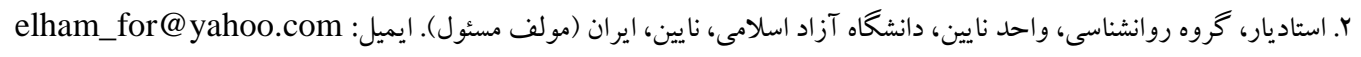

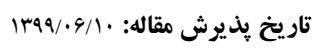

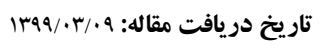

جكيده

مقدمه: نقص در عملكردهاى اجرايى، كنترل رفتار و هيجانات را در اسكيزوفرنيا مختل مى سازد و شناسايى همبستهاى آن مىتواند در

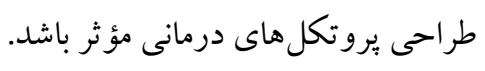

هدف: هدف ئزوهش حاضر بررسى رابطه عملكرد ديدارى -فضايى (ترسيمى) با عملكردهاى اجرايى بيماران اسكيزوفرنياى زن بسترى

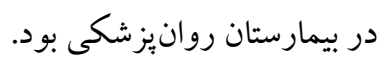

روش: طرح يزوهش توصيفى و از نوع همبستخى بود. جامعه آمارى يزوهش بيماران زن مبتلابه اختلال اسكيزوفرنيا بودند كه از ابتداى

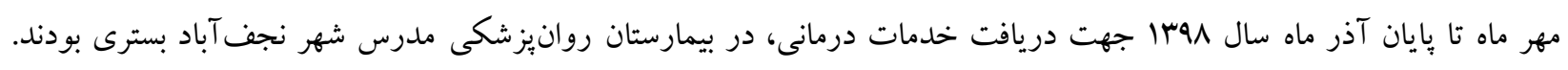
براى انجام اين ئزوش، تعداد •ه نفر، از طريق روش نمونه گيرى هدفمند و بر اساس معيارهاى ورود انتخاب و آزمونهاى كوتاه

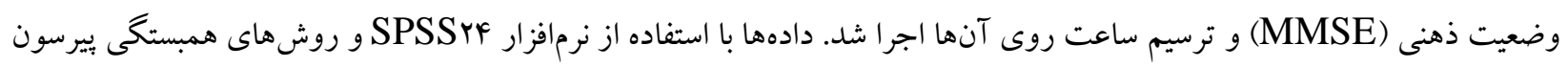

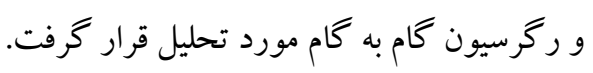

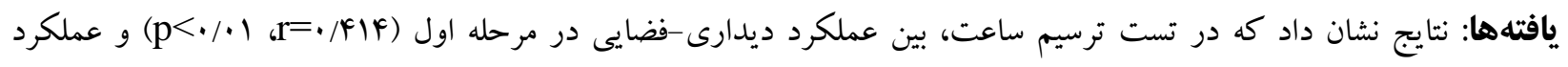

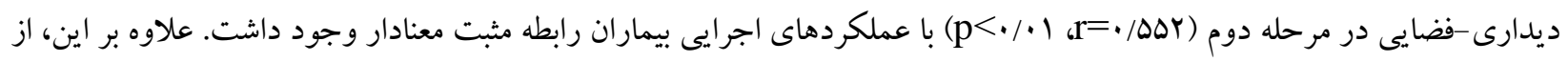

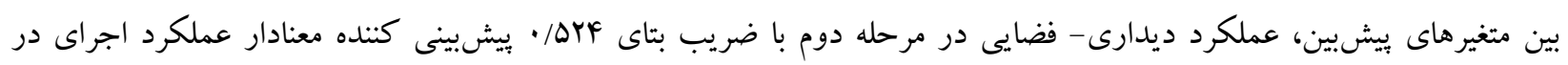

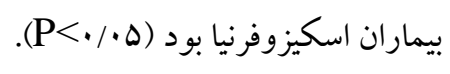

نتيجه كيرى: با ارائه مداخلات توانبخشى شناختى و آموزشهاى به موقع و مناسب مىتوان در جهت تقويت عملكرد ديدارى-

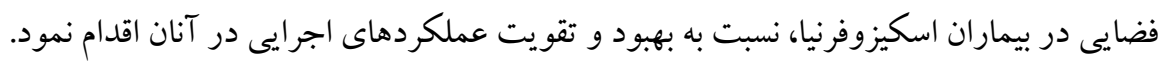
كليدوازهها: اسكيزوفرنيا، عملكرد اجر ايى، عملكرد ديدارى-فضايى 
يكك اختلال شناختى نيست؛ اما سبب ايجاد اختلالاتى در

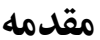
شناخت (مانند تفكر عينى و اختلال در بردازش

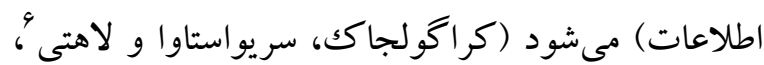

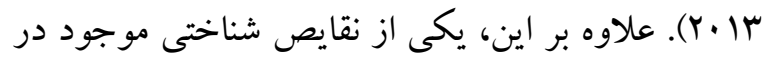

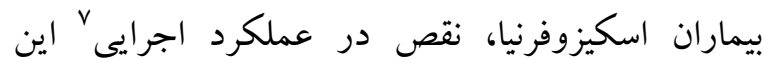

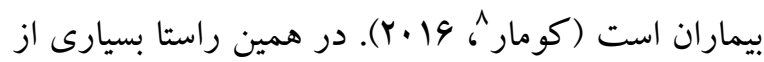
محققان بيشنهاد مى كنند كه اسكيزوفرنيا در درجه اول يكك اختلال فرونتواسترياتال است و اين نقص شناختى اجرايى در طول اين بيمارى بيشرفت مى كند (نيل و

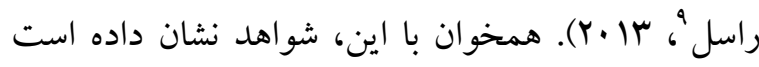
كه در بيماران اسكيزوفرنيا، فعاليت در قشر بروفرونتال خلفى جانبى جِب، قشر كمربندى قدامى، تالاموس جِبِ و مناطقى از قشر خلفى بهطور مداوم با نقص در عملكرد

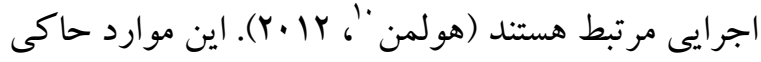
از آن است كه نقص در عملكرد اجرايى بايد بهعنوان يكك مسئله مهم در اختلال اسكيزوفرنيا مطرح كردد (عليز اده صفاو مالمير، عqM I). عملكرد اجرايى كه بهعنوان سيستم كنترل شناختى و و سيستم توجه نظارتى نيز شناخته شده است، به مجموعهاى از فرايندهاى روانشناسى سطح بالا اشاره دارد كه شامل ايده يردازى، فكر كردن بيش از اقدام به كارى، انجام جالش هاى جديد و غيرمنتظره، مقاومت در برابر وسوسه، تمركز، استدلال، حل مسئله و برنامهريزى، اراده، عمل هدفمند، خودتنظيمى و عملكرد مؤثراست (اتكين،

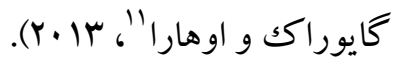

${ }^{6}$ - Kraguljac, Srivastava \& Lahti

7 - Excecutive Function

${ }^{8}$ - Kumar

9- Neill \& Rossell

${ }^{10}$ - Holmen

${ }^{11}$ - Etkin, Gyurak \& O'Hara

اسكيزوفرنيا اختلال روانى بيجيدهاى است كه شديدترين و مخربترين تأثير را بر زندكى فرد بهجا مى گذارد

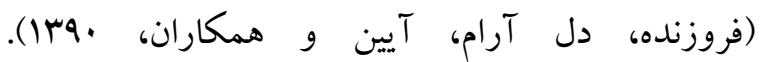
اسكيزوفرنى يكك بيمارى عصبشناختى بيجيده است كه بهوسيله توهمات، خيالات، رفتار غير سازماندهى شده و نقايص شناختى بيشرونده مشخص مىشود (دايك،

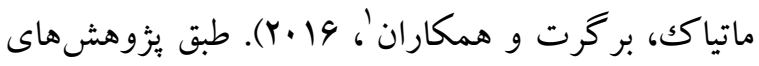
صورت كرفته، ميزان شيوع اختلال اسكيزوفرنيا تقريباً درصد است، بهطورى كه سالانه ه تا ها درصد اين افراد تحت درمان قرار مى گيرند. شيوع اسكيزوفرنيا در مرد و زن برابر است؛ اما در مردها شروع بيمارى زودتر است

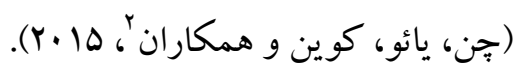
اسكيزوفرنيا يك اختلال روانى روانيريشى با علت ناشناخته است كه با نشانهاى مثبت و منفى (كمبود) مشخص مىشود. نشانهاى مثبت، بيش كاركردهاى رفتارى است كه شامل توهمات، هذيانها، رفتارهاى عجيبوغريب و تفكر مختل است. نشانهاى منفى، نقايص رفتارى هستند كه فقر كفتار، عاطفه سطحى، بى تفاوتى، انزوا و نقص توجه را دربر مى گيرد (ناكامورا،

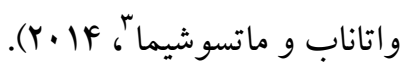
طبق يافتهاى ئزوهشى، فرايندهاى شناختى بيماران اسكيزوفرنيا نارسا و مختل است (آلتامورا، فاجيولينى،

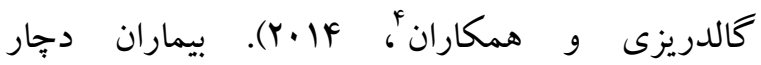
اسكيزوفرنيا معمولاً در حوزههاى توجه، كاركردهاى اجرايى، حافظه فعال و حافظه رويدادى كز كارى خفيفى

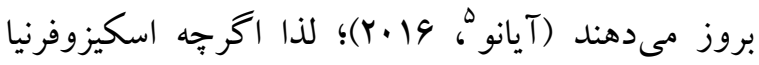

\footnotetext{
1 - Dyck, Mathiak, Bergert \&et al

${ }^{2}$ - Chen, Yao, Qin \&et al

${ }^{3}$ - Nakamura, Watanabe \& Matsushima

4- Altamura, Fagiolini, Galderisi \& et al

5 - Ayano
} 
ادراكى محرك و تمركز فكر (شولمان و فاينستين'، r.r.r. كه در بيماران مبتلابه اسكيزوفرنيا به دليل نقايص شناختى و ادراكى تا حدود زيادى مختل شده است. در

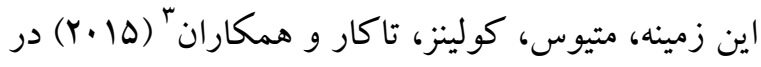
بررسى تصويرسازى ديدارى- فضايى و حافظه كارى در بيماران مبتلابه اختلال اسكيزوفرنيا به اين نتيجه دست يافتند كه عملكرد تصويرسازى ديدارى - فضايى و حافظه كارى در بيماران اسكيزوفرنيا نسبت به افراد عادى داراى

\section{نقص است.}

در جمعبندى نهايى، ازآنجاكه اسكيزوفرنيا ازجمله بيمارىهايى است كه دربر گيرندهى طيف وسيعى از آسيب هاى شناختى، هيجانى و اجتماعى است و مىتواند منجر به بروز نقايص شناختى متعددى در بيماران ازجمله نقص در عملكرد اجرايى آنان شود (كومار، 19 +r) و نيز ازآنجاكه نقص در عملكرد اجرايى، عمليات يردازشى عالى ذهنى را تحت تأثير قرار داده و كنترل افكار و رفتار فرد را با مشكل مواجه مى سازد؛ لذا شناسايى همبستها و و عوامل مرتبط با آن ضرورى است. علاوه بر اين، نظر به اينكه توانايىهاى فضايى ازجمله همبسته هاى كار كردهاى اجرايى در افراد هستند؛ بنابراين بررسى رابطه توانايىهاى فضايى مانند عملكرد ديدارى- فضايى با عملكردهاى اجرايى در بيماران اسكيزوفرنيا از اهميت بسيار زيادى برخوردار است. همبجنين از آنجا كه بر اساس بررسىهاى محقق، تاكنون بُزوهشى در داخل كشور به بررسى رابطه

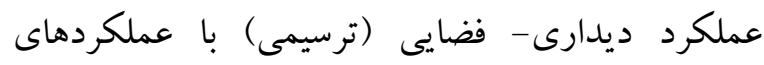
اجرايى بيماران اسكيزوفرنيا نبرداخته است؛ لذا در اين زمينه خلأ يُوهشى وجود دارد؛ بنابراين، يُوهش حاضر

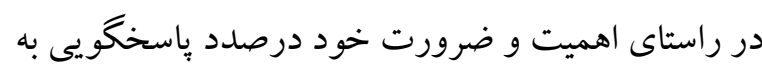

2- Shulman \& Feinstein

${ }^{3}$ - Matthewsa, Collinsb, Thakkar \& et al
قابل توجه است كه رشد عملكرد اجرايى در تكامل ساير توانيىهاى فردى نقش ايفا مى كند (موسى زادكان و و

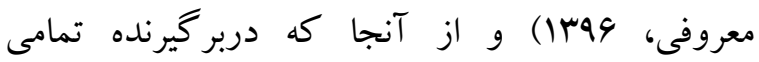
فرايندهاى شناختى بيجيده مورد نياز براى انجام تكاليف

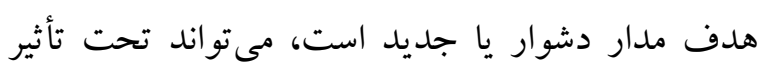

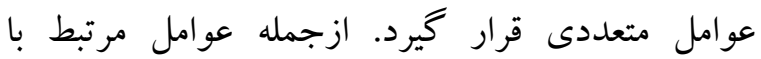
عملكرد اجرايى در افراد، توانايىهاى فضايى هستند (تقى عري

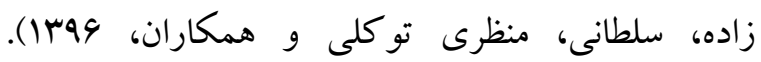
تو انايى هاى فضايى، مهارت هاى شناختى مهمى هستند كه بهعنوان مهارتهاى مورد نياز براى توليد، نخهدارى و انتقال تصاوير ديدارى- انتزاعى مىتواند تعريف شود و داراى ابعاد گوناگونى است (نقل از فريد، حبيبى، داداشى

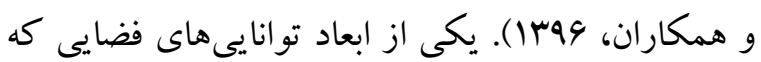
با نقايص شناختى و عملكردهاى اجرايى افراد مرتبط استو

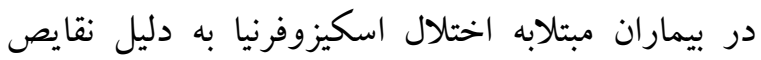
موجود در عملكردهاى اجرايى و شناختى، مختل شده

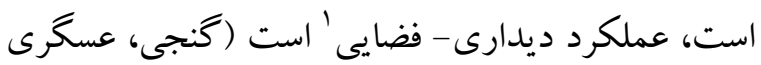
و تركاشوند، •وrا). يكى از شيوههاى بررسى عملكرد ديدارى- فضايى در افراد، روش ترسيمى است كه دربر گيرنده مجموعهاى از فرايندهاى شناختى، ذهنى و ادراكى بهمنظور نخهاشت و دست كارى اطلاعات مورد نياز براى انجام فعاليت ترسيم است (شفيعى، فخاريان، اميدى و همكاران، هوبا1). برخى از اين فرايندهاى ذهنى و شناختى و ادراكى موردنياز براى ترسيم عبارتاند از توجه، درك مطلب (شنيدارى)، برنامهريزى، مرور ذهنى، حافظه بينايى و بازسازى تصاوير ذهنى، توانايىهاى

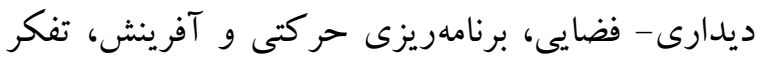
انتزاعى، بازدارى گرايش به جلب شدن به ويز خى بهاى

\footnotetext{
1. Visio-Spatial Function
} 
اساس يرونده يزشكى بيمار، عدم همكارى آزمودنى در

$$
\text { اجر ایى آزمونها. }
$$

بدين منظور پِ إز مراجعه به بيمارستان روانيزشكى

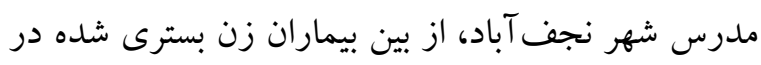
بيمارستان كه واجد معيارهاى ورود به بيزوهش بودند، تعداد •ها نفر به عنوان گروه نمونه انتخاب شدند. جهات رعايت نكات اخلاقى بثزوهش، در آغاز هدف از اجراى يثزوهش براى كليه زنان بسترى مبتلا به اسكيزوفرنيا شرح داده شد و با تأكيد بر محرمانه بودن اطلاعات و حفظ برون رازدارى به اين مطلب اشاره شد كه نيازى به ذكر نام و نام

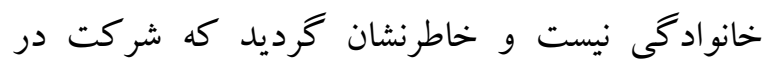
آزمون اختيارى است و در حين اجراى آزمون نيز

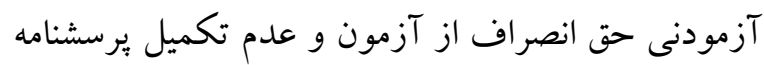
را دارد. هميجنين تأكيد شد كه اطلاعات شخصى شر كت كنند گان به صورت محرمانه نگه داشته مىشود و سبِ يرسشنامها و آزمونها ميان زنان مبتلابه اسكيزوفرنياى بسترى در بيمارستان روانيزشكى توزيع و نسبت به جمع آورى دادههاى مورد نياز اقدام شد. درنهايت، دادههاى حاصل، با استفاده از نرمافزار SPSS نسخهى YF انجام شد و در دو بخش توصيفى (ميانگين و انحراف استاندارد) و استنباطى (روشهاى همبستخى لهیى ييرسون و تحليل رگرسيون گام به گام) مورد تحليل قرار

يرسشنامه اطلاعات جمعيت شناختى: يرسشنامهاى حاوى سؤالات دمو گرافيكك شامل سن، ميزان تحصيلات، وضعيت تأهل و مدت زمان بيمارى.
اين سؤال است كه آيا بين عملكرد ديدارى- فضايى ) (ترسيمى) با عملكردهاى اجرايى بيماران اسكيزوفرنياى زن بسترى در بيمارستان روان يزشكى رابطه وجود دارد؟

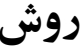

طرح بثزوهش توصيفى و از نوع همبستكى بود. جامعه آمارى ئزوهش حاضر كليه بيماران زن مبتلابه اختلال اسكيزوفرنيا بودند كه در باييز (مهر و آبان و آذر) سال ^هوا جهت دريافت خدمات درمانى در بيمارستان روانيزشكى مدرس شهر نجف آباد بسترى بودند. در اين يثزوهش از روش نمونه گيرى هدفمند استفاده شد. تعداد آنها بر اساس آمار دريافتى از بيمارستان، 9.1 نفر بود. حجم نمونه در بثزوهش حاضر بر اساس بررسى

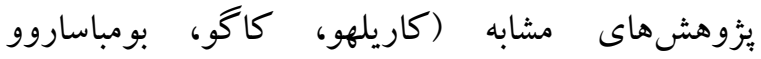

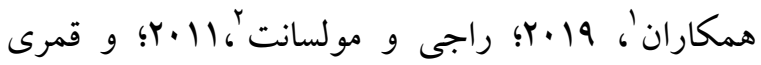
كيوى و قاسمنزاد، IMNV و كافى بودن ازنظر آمارى و نيز بر اساس تعداد نمونهاى واجد معيارهاى ورود و خروج جهت شركت در بزوهش، ·له نفر در نظر كرفته

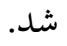
معيارهاى ورود به يزوهش عبارت بودند از: جنسيت زن،

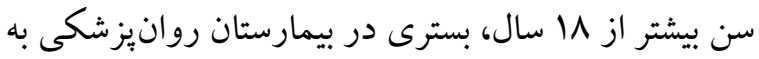
دليل ابتلا به بيمارى اسكيزوفرنى بر اساس نظر روانيزشك، كذشت حداقل r سال از زمان ابتلا به بيمارى اسكيزوفرنيا، داشتن حداقل تحصيلات سيكل جهت دركك و توانايى اجراى آزمونها، داشتن رضايت جهت شركت در يثزوهش. معيارهاى خروج از يزوهش نيز عبارت بودند از: سوء مصرف الكل و مواد مخدر بر

\footnotetext{
1- Carrilho, Cougo, Bombassaro \& et al

2- Rajji \& Mulsant
} 


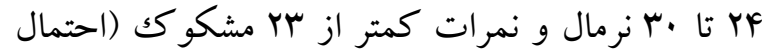
وجود اختلال) را نشان مىدهد. سيديان، فلاح، نوروزيان

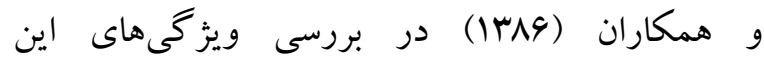
روانسنجى اين آزمون، روايى آن را مورد تائيد قرار داده و ضريب آلفاى كرونباخ را براى كل آزمون |ی/. به دست آوردند كه نشان دهنده مطلوب بودن پايايى اين

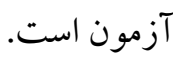
آزمون ترسيم ساعت لٌ آزمون ترسيم ساعت براى نخستين بار به وسيلهى شولمن در سال 1919 به عنوان شاخصى براى نقصانهاى شناختى به ويزه آيراكسى ساختارى و

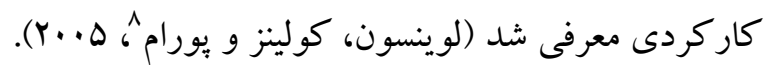
آزمون ترسيم ساعت به هر نوع نقصان شناختى حساس است. اين آزمون براى شناسايى اختلالات شناختى، آيراكسى ساختارى، عملكرد اجرايى و نيز شناسايى انواع دمانس و برخى ديخر از آسيبهاى نورولوزيكى از سال 1919 به كار برده شده است (بوزيكاس، كاسميديس،

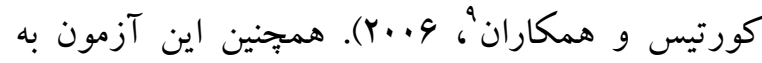
تغيير عملكرد بينايى- تحليلى حساس است و بازنمايى

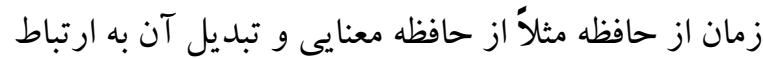
ديدارى- فضايى، به وسيله اين آزمون ارزيابى مىشود. اين آزمون داراى fl آيتم است و اشكال در قرار دادن شمارهها در جاى صحيح، ناتوانى در نشان دادن دقيقهاى مورد نظر، جابجا قرار دادن دقيقه شمار در شمارههاى دقيقه و ناتوانى در ترسيم عقربه دقيقه شمار درازتر، از جمله خطاهاى برجسته بيماران مبتلا به اسكيزوفرنيا بودهاند (قمرى گيوى و قاسمنزاد، اين آزمون، هِ از توجيه آزمودنىها در خصوص اهداف، آزمون طى دو مرحله به صورت انفرادى اجرا

7- Clock Drawing Test (CDT)

${ }^{8}$ - Levenson, Collins \& Puram

${ }^{9}$ - Bozikas, Kosmidis, Kourtis \&et al
آزمون كوتاه وضعيت ذهنى'؛ اين آزمون به منظور غربالخرى زوال عقلى در سال 19VD توسط فولستين ابداع كرديد. در آن زمان آزمونهاى متعددى جهت ارزيابى اعمال شناختى وجود داشت؛ اما تمامى آنها بسيار طولانى بوده و جهت بررسى بالينى مناسب نبودند. آزمون كو تاه وضعيت ذهنى داراى ·. سؤ ال است كه فولستين آنها را از ميان آزمونهاى قبلى موجود انتخاب كرده است. اعمال شناختى كه در اين آزمون مورد ارزيابى قرار

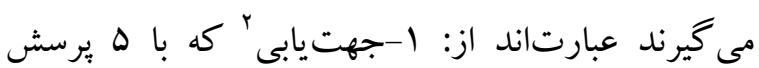
درباره زمان و ه هرسش درباره مكان سنجيده مىشود، بـ

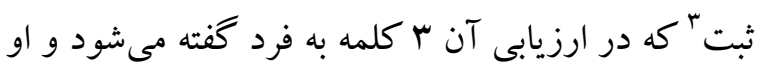
بايد آنها را تكرار كند. ب- توجه-محاسبه --كه در ارزيابى آن فرد بايد از عدد . ․ بهطور متوالى V عدد كم نمايد يا يكك كلمه را معكوس بيان نمايد. F- حافظه اخيره كه در آن از فرد خو استه مى شود سه كلمه قبلى را تكرار نمايد. ه- عملكردهاى مختلف زبانى: فرد بايد ساعت و

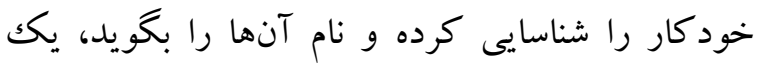
جمله را تكرار كند. بايد يكك دستور سه مرحلهاى را اجرا كند، اين جمله را بخواند و اجرا كند: (جشمهايت را ببند)" و يكك جمله كامل بنويسد. 9- تفكر فضايى: كه در آن از بيمار خواسته مىشود دو ينج ضلعى متقاطع را كيى كند. باسخ به هر سؤال، صحيح يا نادرست بوده، امتياز كلى بر

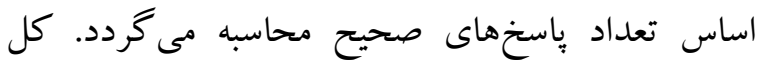

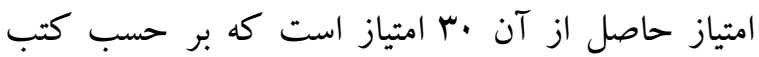
مرجع نمره كمتر از ها به احتمال وجود اختلال شناختى

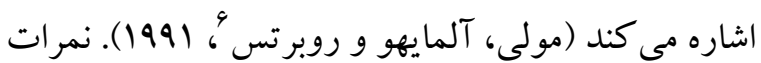

\footnotetext{
1- Mini Mental Status Examination(MMSE)

2. Orientation

3 - Registration

${ }^{4}$ - Attention- Calculation

5 - Recent memory

6. Molloy, Alemayehu \& Roberts
} 
بايايى M// • را براى آن گزارش نمودهاند (كانكاز و

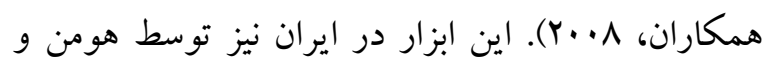

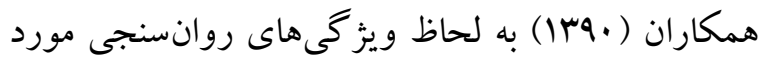

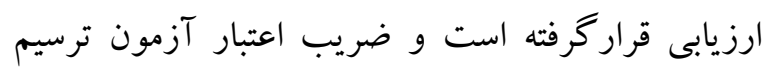

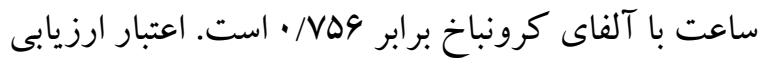

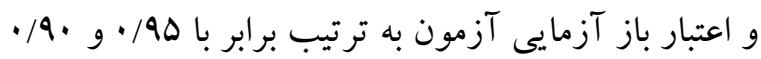
محاسبه شد (هومن و همكاران، •وسار).

\section{يافتهها}

شركت كند كان در يزوهش حاضر از نظر جنسيت همخى زن بودند و از نظر سابقه بسترى نيز همخى داراى سابقه

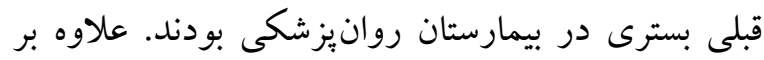
اين، حداقل و حداكثر سن بيماران اسكيزوفرنياى

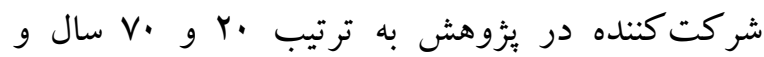

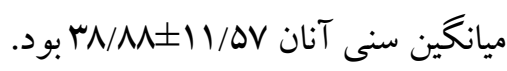
از نظر سطح تحصيلات، از بين ·ه بيمار اسكيزوفرنياى

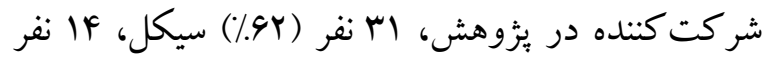

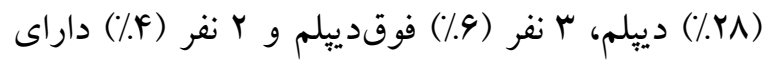
تحصيلات در سطح ليسانس بودند. ازنظر وضعيت تأهل

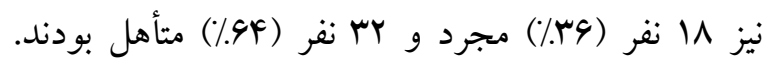
جدول ا ميانگين و انحراف معيار نمرات عملكردهاى اجر ايى و حيطههاى مختلف آن را نشان مىدهد.
مىشود. مرحله اول بدون راهنمايى و مرحله دوم با

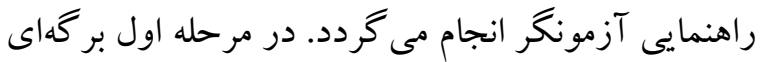
جلوى آزمودنى قرار داده شده و به آزمودنى گفتهن مى شود: (براى من ساعتى بكش كه شمارهها و عقربهها را

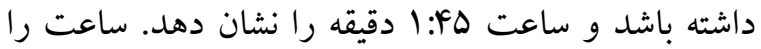
به كونهاى بكش كه حتى اخر بجِهاى به آن نغاه كند، بتواند آن را بخواند.) اين دستورالعمل به آزمودنى تاكي وقتى كه آن را به طور كامل درك كند و بفهمد گفتنه

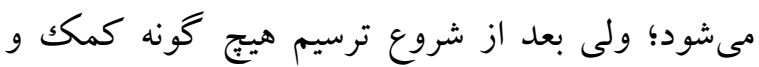

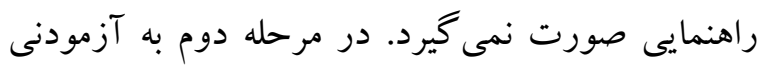
كفته مىشود: | حالا در اين سمت صفحه در اين دايره (دايرهاى كه از اول بر روى بركه تهيه شده است نشان

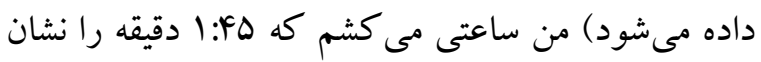

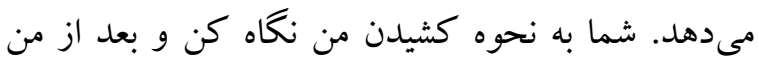
شما به همين شكل ساعت را بكش". بِ بساز آن آيتمها مطابق دستو رالعمل CLOX نمره خذارى مىشوند.

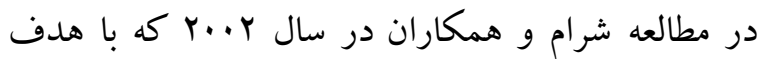
بررسى قابليت انجام اين آزمون براى آسيبهاى شناختى

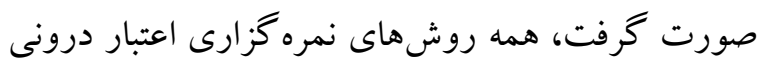

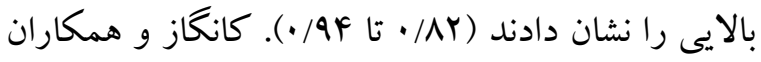
نيز آزمون ترسيم ساعت را بر روى بزر گسالان (r.人)

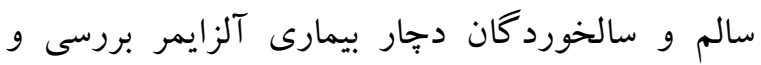

\section{جدول ا ميانكين و انحراف معيار نمرات عملكردهاى اجرايى}

\begin{tabular}{|c|c|c|c|}
\hline تعداد & انحر اف معيار & ميانكين & متغير \\
\hline$\Delta$. & 1/VQ & r & آكاهى به زمان \\
\hline$\Delta$. & $1 / 14$ & $r / A$. & آكاهى به مكان \\
\hline$\Delta$. & $1 / Y 1$ & F/FF & يادآورى \\
\hline$\Delta$ & $\cdot / \wedge$ & $\cdot / 9$. & توجه و محاسبه \\
\hline$\Delta$. & $1 / 14$ & $1 / 91$ & اشاره به خود كار و ساعت \\
\hline$\Delta$. & $\cdot / r \Delta$ & $1 / \cdot r$ & تكرار يكك جمله بدون معنا \\
\hline
\end{tabular}




\begin{tabular}{|c|c|c|c|}
\hline$\Delta$. & $\cdot / V F$ & $r / F A$ & كرفتن كاغذ و تا كردن \\
\hline$\Delta \cdot$ & 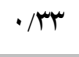 & $\cdot / M$ & خواندن جمله و انجام عمل \\
\hline$\Delta \cdot$ & $\cdot / f F$ & $\cdot / \mathrm{V}^{\mathrm{F}}$ & نوشتن يكك جمله \\
\hline$\Delta$. & $\cdot / A V$ & $\cdot / 91$ & كيى كردن ه ضلعى \\
\hline$\Delta$ & $F / \mu$ & IN/AF & نمره كل عملكردهاى اجرايى \\
\hline
\end{tabular}

مربوط به آيتم ياد آورى با ميانگين و انحر اف معيار F/FF

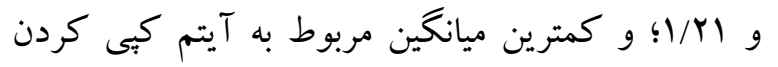

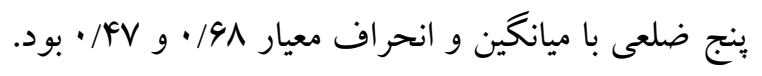
جدول r ميانگين و انحراف معيار نمرات عملكرد ديدارى- فضايى و حيطههاى مختلف آنها را نشان مى -

دهد.
همان كونه كه در جدول فوق مشاهده مىشود، ميانخين و انحراف معيار نمره كل عملكردهاى اجرايى در بيماران زن اسكيزوفرنياى شركت كننده در بثوهش به ترتيب 1 M/AF حيطهاى مختلف آزمون كوتاه وضعيت ذهنى در جدول فوق قابل مشاهده است كه بر اين اساس، بيشترين ميانگين

جدول r ميانكين و انحر اف معيار نمرات عملكرد ديدارى-فضايى (ترسيمى)

\begin{tabular}{|c|c|c|c|c|c|}
\hline تعداد & انحراف & ميانكين & مرحله & آيتمها & رديف \\
\hline$\Delta$. & ס & $\cdot / 19$ & اول & شباهت شكل به ساعت & 1 \\
\hline$\Delta$. & $\cdot / \mu$ & $\cdot / 9$ & 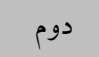 & & \\
\hline$\Delta \cdot$ & $\cdot / r$ &.$/ 94$ & اول & وجود داشتن محيط بيرونى ساعت & r \\
\hline$\Delta$. & $\%$ & 1 & دوم & & \\
\hline$\Delta$ & $\cdot / 4$ & $\cdot / A \cdot$ & اول & قطر>l اينج ( T/DF سانتىمتر) & r \\
\hline$\Delta \cdot$ & $\cdot / \mathrm{TV}$ &.$/ 94$ & 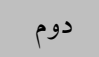 & & \\
\hline$\Delta \cdot$ & $\cdot / 4 \pi$ & .191 & اول & وجود همه شمارهها درون ساعت & r \\
\hline$\Delta \cdot$ & $\cdot / \mu$ & $\cdot / \mathrm{V}$ & 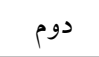 & & \\
\hline$\Delta \cdot$ & $\cdot / T V$ & .119 & اول & 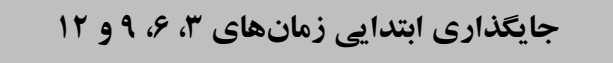 & $\Delta$ \\
\hline$\Delta \cdot$ & ו ו &.$/ 11$ & 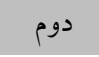 & & \\
\hline$\Delta \cdot$ &.$/ 90$ & $1 / r F$ & اول & جايكذارى صحيح اعداد و تقارن در هر دو طرف & \& \\
\hline$\Delta \cdot$ &.$/ 99$ & $1 / \Gamma$ & 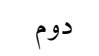 & & \\
\hline$\Delta$ & $\cdot / 49$ & $\cdot / \Delta \Lambda$ & اول & شماره كذارى انكليسى يا فارسى & $\checkmark$ \\
\hline$\Delta$. & $\cdot / A Y$ & $\cdot /$ No & 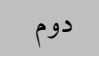 & & \\
\hline$\Delta \cdot$ & $\cdot / \Delta$ & $\cdot 109$ & 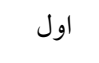 & فقط انتليسى يا فقط فارسى نوشتن همه اعداد & $\wedge$ \\
\hline$\Delta \cdot$ & $\cdot / 4 \mathrm{~V}$ & $.19 \mathrm{~V}$ & 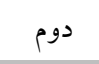 & & \\
\hline$\Delta$. & $\cdot / 4 \Lambda$ & $\cdot / 49$ & 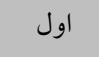 & توالى صحيح اعداد ا تا r| & 9 \\
\hline$\Delta$. & $\cdot / A V$ & .19 & 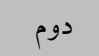 & & \\
\hline$\Delta$ & $\cdot / 49$ & .191 & 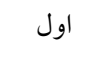 & وجود فقط r عقربه & 1. \\
\hline$\Delta \cdot$ & $\cdot / \Delta$ & $\cdot / 4 \Lambda$ & 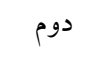 & & \\
\hline
\end{tabular}




\begin{tabular}{|c|c|c|c|c|c|}
\hline $\begin{array}{l}\Delta . \\
\Delta .\end{array}$ & $\begin{array}{l}\cdot / 4 q \\
. / \Delta\end{array}$ & $\begin{array}{l}\cdot 194 \\
\cdot / 09\end{array}$ & دوم & نشان دادن هر دو عقربه بلصورت فلش & 11 \\
\hline$\Delta$. & $\cdot / Y V$ & $\cdot / \cdot 1$ & اول & عقربه ساعت شمار بين ساعت ا و † & ir \\
\hline$\Delta$. & $\cdot / Y F$ & .1 .9 & 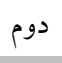 & & \\
\hline$\Delta$. & $\cdot / 4 q$ & $\cdot / \mu$ & 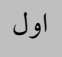 & عقربه دقيقهشمار درازتر از عقربه ساعت شمار & ir \\
\hline$\Delta \cdot$ & $\cdot / r q$ & $\cdot / 1 \Lambda$ & دوم & & \\
\hline$\Delta \cdot$ & 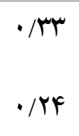 & $\cdot / M$ & دوم & 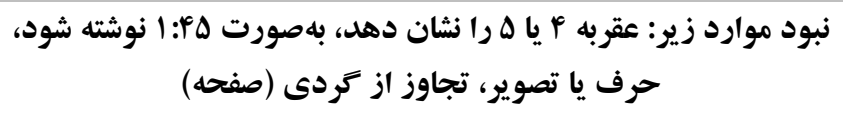 & if \\
\hline$\Delta$. & $r / v$. & $\Lambda / \wedge \Delta$ & اول & نمره كل & - \\
\hline$\Delta$. & $r / r \mu$ & $9 / 11$ & 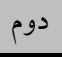 & & \\
\hline
\end{tabular}

بيش از انجام تحليل استباطى دادهها (روشهاى

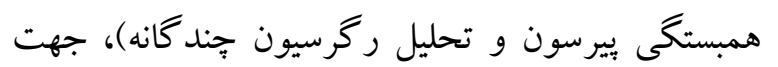

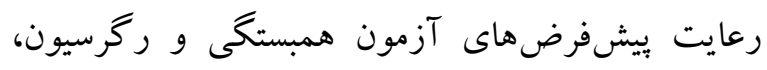
مهمترين بيشفرض يعنى بررسى نرمال بودن توزيع

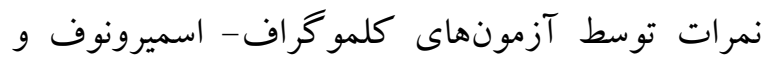
شاييرو-ويلك مورد بررسى قرار گرفت كه نتايج آن در جدول شماره ب قابل مشاهده است.
همان گونه كه در جدول Y مشاهده مىشود، ميانگين و انحراف معيار نمره كل عملكرد ديدارى فضايى (ترسيمى) در بيماران زن اسكيزوفرنياى شركت كننده در

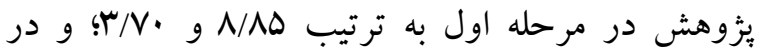
مرحله دوم 9/11 و س/r/ بود كه نشان دهنده افزايش نمرات عملكرد ديدارى- فضايى در مرحله دوم نسبت به مرحله اول بود.

جدول ب نتايج آزمون كلموكراف - اسميرونوف و شإيرو - ويلك در مورد ييش فرض نرمال بودن نمرات كليه متغيرها

\begin{tabular}{|c|c|c|c|c|c|c|}
\hline \multicolumn{3}{|c|}{ شاييرو-ويلك } & \multicolumn{3}{|c|}{ كلمو كر اف- اسميرنوف } & \multirow[t]{2}{*}{ متغيرها } \\
\hline سطح معنادارى & درجه آزادى & Tاره & سطح معنادارى & درجه آزادى & آماره & \\
\hline$\cdot /$ MAF & $\Delta$. & $\cdot / 991$ &.$/ .99$ & ه. &.$/ 110$ & عملكردهاى اجرايى \\
\hline $.1 . \Delta 9$ & $\Delta$. & . A4r & $\cdot / 190$ & $\Delta$. &.$/ 1.9$ & نمره كل عملكرد ديدارى-فضايى \\
\hline
\end{tabular}

بررسى رابطه بين عملكرد ديدارى- فضايى (ترسيمى) با عملكردهاى اجرايى بيماران اسكيزوفرنيا، از ضريب لريب

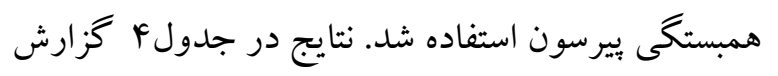
شده است.
براساس نتايج حاصل از جدول شماره س، سطح معنادارى براى هيج يكك از متغيرها در هيج كدام از آزمونها معنىدار نبود (ه>/p)؛ بنابراين شرايط نرمال بودن توزيع نمرات به درستى رعايت شده بود. به منظور

جدول f ضرايب همبستكى بيرسون بين عملكرد ديدارى-فضايى (ترسيمى) با عملكردهاى اجر ايى بيماران

\begin{tabular}{|c|c|c|c|}
\hline عملكرد ديدارى -فضايى & عملكرد ديدارى-فضايى & عملكردهاى اجرايى & متغيرها \\
\hline
\end{tabular}




\begin{tabular}{|c|c|c|c|}
\hline & & 1 & عملكردهاى اجرايى \\
\hline & 1 & $* * \cdot /$ f If & عملكرد ديدارى-فضايى (مرحله اول) \\
\hline 1 & $* * \cdot / V 1 \Delta$ & $* * \cdot / \Delta \Delta r$ & عملكرد ديدارى -فضايى (مرحله دوم) \\
\hline
\end{tabular}

اجرايى در بيماران اسكيزوفرنيا همراه است. براى بررسى

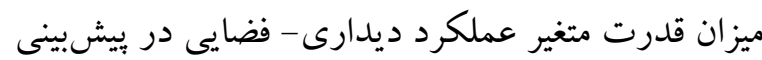
عملكرد اجرايى بيماران اسكيزوفرنيا شركت كننده در

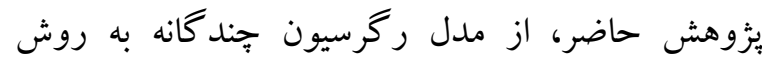
Stepwise
با توجه به نتايج حاصل از جدول fأه بين عملكرد ديدارى- فضايى در مرحله اول (r=*/F|f) و عملكرد

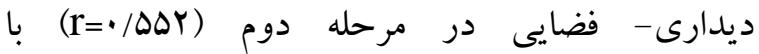
عملكردهاى اجرايى بيماران اسكيزوفرنياى شركت كننده

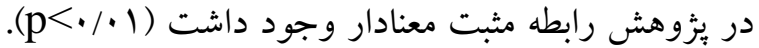
بدين معنى كه افزايش (بهبود) عملكرد ديدارى- فضايى در بيماران اسكيزوفرنيا، با افزايش (بهبود) عملكردهاى

جدول ه نتايج مدل ركر سيون عملكرد ديدارى-فضايى مرتبط با عملكردهاى اجرايى بيماران اسكيزوفرنيا

\begin{tabular}{|c|c|c|c|c|c|c|}
\hline سطح معنادارى & $\mathbf{F}$ & ضريب تعيين (R) & ميانكين مربعات & درجه آزادى & مجموع مربعات & منبع تغييرات \\
\hline$\cdot / \cdots$, & $1 . / \pi 19$ & $\cdot / \mu \cdot \Delta$ & $\mid \mathrm{FT} / \mathrm{DIV}$ & r & $r A V / \cdot r \Delta$ & ركرسيون \\
\hline & & & $1 r / 9 \cdot 1$ & FV & $90 \% / 9 \wedge \Delta$ & باقيمانده \\
\hline & & & & 19 & $Q F \cdot / V Y$. & جمع \\
\hline
\end{tabular}

بينى عملكرد اجرايى بيماران اسكيزوفرنيا است، نتايج جدول فوق نشانگر اين است كه عملكرد ديدارى-فضايى در مراحل اول و دوم مجموعاً اس درصد واريانس

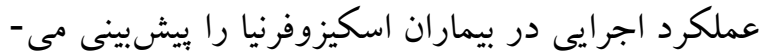

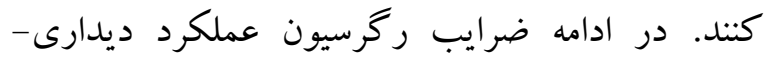
فضايى در مراحل اول و دوم و آزمون معنادارى آنها جهت تعيين سهم هر كدام از متغيرهاى بيشبين محاسبه و ون در جدول 9 ارائه شده است.
براساس نتايج حاصل از جدول ه، با توجه به اينكه مقدار

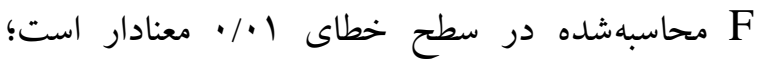
بنابراين مدل رگرسيون خطى معنادار است (1) (1)؛ لذا مىتوان كفت حداقل يكى از متغيرهاى ييشبين (عملكرد ديدارى-فضايى در مرحله اول يا مرحله دوم) مىتوانند متغير ملاكك (عملكرد اجرايى) را در بيماران اسكيزوفرنيا بيشبينى نمايد. علاوهبر اين، با توجه به اينكه

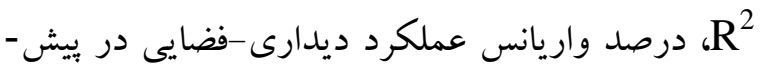

جدول و ضرايب ركرسيون عملكرد اجرايى مرتبط با عملكرد ديدارى-فضايى در بيماران اسكيزوفرنيا

\begin{tabular}{|c|c|c|c|c|c|}
\hline \multirow[t]{2}{*}{ سطح معنادارى } & \multirow[t]{2}{*}{ t t t t } & \multirow{2}{*}{ ضرايب استاندارد } & \multicolumn{2}{|c|}{ ضرايب غيراستاندارد } & \multirow[t]{2}{*}{ مدل } \\
\hline & & & خطاى معيار & B & \\
\hline$\% \cdots 1$ & $V / r \Lambda V$ & & $1 / 911$ & $11 / 9 \Delta \Delta$ & ثابت \\
\hline$\cdot /$ Arr & $\cdot /$ TrS & $\cdot / \cdot r q$ & $\cdot / 4 \cdot 4$ &.$/ .49$ & عملكرد ديدارى-فضايى (مرحله اول) \\
\hline$\% \mu$ & $r / \cdot 11$ & $\cdot / \Delta Y F$ & . / M & $\cdot / 211$ & عملكرد ديدارى-فضايى (مر حله دوم) \\
\hline
\end{tabular}




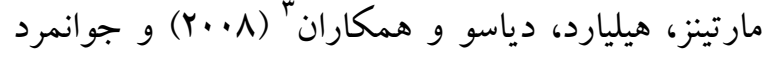

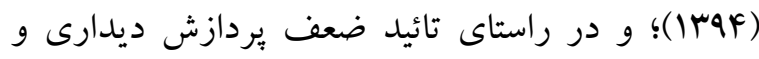
نقص عملكرد ديدارى-فضايى در بيماران اسكيزوفرنيا و نيز با يافتهاى متيوس، كولينز، تاكار و همكاران (ها (Y)،

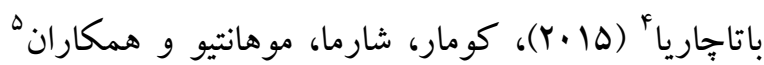

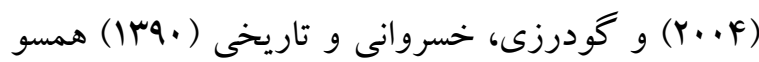
است. در اين زمينه، همجنين رانسينك، خاريكار، ميشرا و و

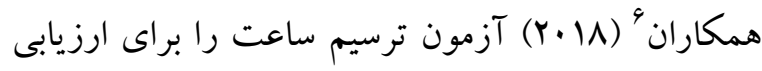
عملكرد شناختى بيماران اسكيزوفرنيا ابزارى مناسب رابر آرياب معرفى نمود. علاوه بر اين، قمرى گيوى و قاسم نزاد (IrAV) اختلالات قشر مغز در بيماران اسكيزوفرنيا، نشان دادند كه

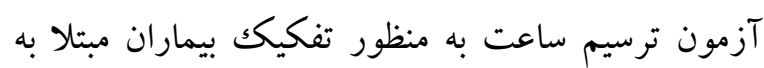
اسكيزوفرنيا از افراد مشكو كك قابل استفاده است خرا كه به ضمن ترسيم، به خوبى اختلال در عملكرد ديدارىفضايى اين بيماران را نشان مىدهد. در يكك تبيين براى يافتهاى به دست آمده از اين يُزوهش مىتوان به جايگاه مغزى مشابه براى عملكرد ديدارى- فضايى و عملكرد اجرايى در افراد اشاره نمود. براساس يزوهشهاى انجام شده، نقش مهم قشر بيش

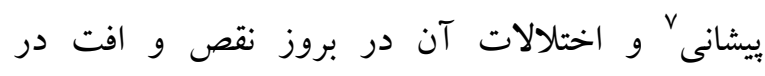
كاركردهاى اجرايى در بيماران اسكيزوفرنيا انكار نايذير است (قديرى، جزايرى، عشايرى و همكاران، هـrا). در

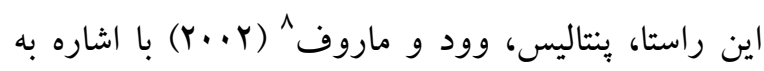

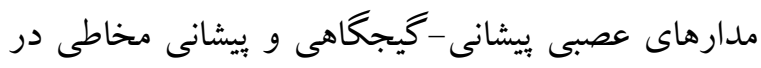
اسكيزوفرنيا، خاطر نشان مى سازند كه كز كارى قشر بيش

3. Martinez, Hillyard, Dias \& et al

4- Bhattacharya

5 - Kumar, Sharma, Mohanty \& et al

${ }^{6}$ - Ransing, Khairkar, Mishra \& et al

7. Orbitofrontal

${ }^{8}$ - Pantelis, Wood \& Maruff
نتايج جدول 9 نشان مىدهد كه از بين متغيرهاى بيشبين، عملكرد ديدارى فضايى در مرحله دوم با ضريب بتاى

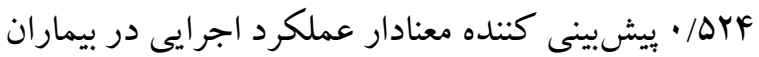

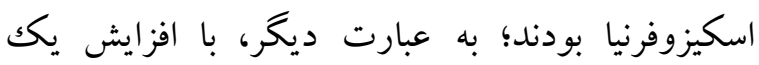
انحراف استاندارد در نمره اين متغير، نمرات عملكرد

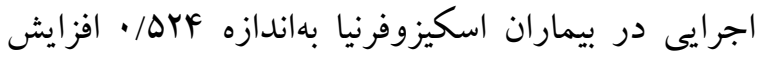
مى يابد. اين در حالى است كه عملكرد ديدارى-فضايى در مرحله اول قادر به بيشيينى معنادار عملكرد اجرايى

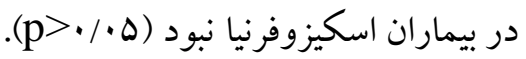

هدف يزّوهش حاضر بررسى رابطه بين عملكرد ديدارى فضايى (ترسيمى) با عملكردهاى اجرايى بيماران اسكيزوفرنياى زن بسترى در بيمارستان روانيز شكى بو بود. نتايج حاصل از تحليل دادهها نشان داد كه بين عملكرد ديدارى- فضايى در مرحله اول و عملكرد ديدارىفضايى در مرحله دوم با عملكردهاى اجرايى بيماران اسكيزوفرنياى شركت كننده در ئزوهش رابطه مثبت وجود داشت. علاوه بر اين، از بين متغيرهاى بيشبين، عملكرد ديدارى فضايى در مرحله دوم بيشيينى كننده معنادار عملكرد اجرايى در بيماران اسكيزوفرنيا بود. نتايج حاصل از اين يُزوهش با يافتههاى راجى و مولسانت (r.11) همسو است كه دريافتند توانايىهاى تجسمى و فضايى در بيماران اسكيزوفرنيا با نشانهاى آسيب درعملكرد اجر ايى آنان در ارتباط هستند. همجنين، نتايج حاصل از اين فرضيه در راستاى تائيد ضعف عملكردهاى اجرايى در بيماران اسكيزوفرنيا با يافتههاى سريوانستاوا و

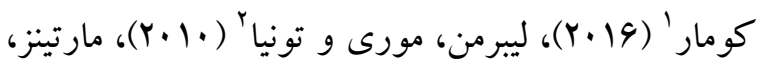

\footnotetext{
1- Srivastava \& Kumar

2- Lieberman, Murray \& Tonia
} 
فوقانى در اسكيزوفرنيا باشد كه در يثزوهش آندرسن نيز بر آنها تأكيد شده است. نتيجه جالب توجه اين است كه حتى بِ از آموزش و مشاهده نحوه كار

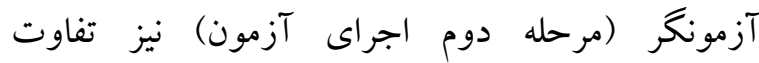
معنى دارى در عملكرد بيماران روى نمىدهد و بسيارى از آيتمها هيج گونه تغييرى نمى كنند و همين موضوع وجود كاركردهاى نارسا در قشر مغزى بيماران اسكيزوفرنيا را تائيد مى كند. به طور كلى ترسيم ساعت مستلزم يكك فهم درست از وضعيت قرارگيرى شمارهها در درون صفحه داشته و همين يك كنش مربوط به فهم روابط فضايى است و مستلزم درك صحيح از جايگاه هر شماره روى صفحه و قرارگيرى هر شماره نسبت به يكديخر و نيز نسبت به خود بيننده هست و همه اينها نيازمند

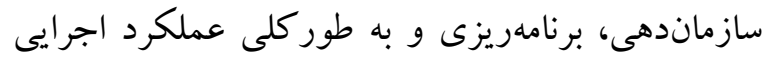

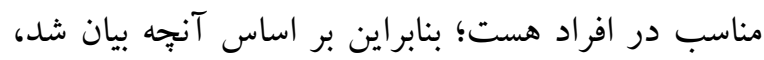

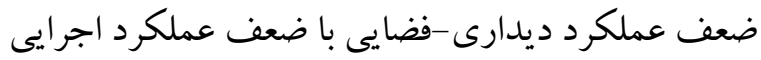
در بيمار ان اسكيزوفرنيا مرتبط است.

\section{نتيجه كيرى}

براساس نتايج به دست آمده از ئوهش حاضر، مىتوان نتيجه گرفت كه عملكردهاى اجرايى توانايىهاى شناختى بـى سطح بالايى شامل كنترل توجه، مهار شناختى، كنترل مهارى، حافظه كارى و انعطاف يذيرى شناختى است كه داراى همبستهاى مختلفى از قبيل عملكرد ديدارىفضايى است؛ لذا توجه به اين عوامل مىتواند متخصصان را در طرحريزى و اجراى برنامههاى بازتوانى شناختى و توانبخشى شناختى بيماران اسكيزوفرنيا يارى نمايد.

${ }^{2}$ - Andreasen
ييشانى نقش محورى را در اين اختلال داشته و درگيرى ساير ساختارهاى مغزى تقريباً هميشه وابسته به ارتباطشان با قشر بيش بيشانى است. از طرف ديخر، شواهد زيادى نشان مىدهند كه قشر ييش بيشانى از مكانهاى مغزى

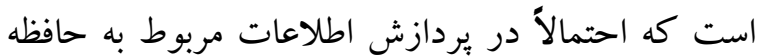

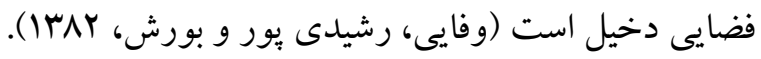
بر اين اساس بين عملكردهاى اجرايى و عملكرد ديدارى-فضايى در اين بيماران ارتباط وجود دارد و از آنجا كه در بيماران اسكيزوفرنيا كز كارى در قشر بيش ييشانى وجود دارد؛ بنابراين هم عملكردهاى اجرايى و هم عملكرد حافظه فضايى در اين بيماران با محدوديتهاى جدى روبرو است. علاوه بر اين، در بزظوهش حاضر نشان داده شد كه بيماران اسكيزوفرنيا در ترسيم ساعت با خطاهاى متعددى مواجه مىشوند. در اين زمينه، همجينين قمرى گيوى و قاسم نزاد (IMAV) اختلالات قشر مغز در بيماران اسكيزوفرنيا، نشان دادند كه آزمون ترسيم ساعت به منظور تفكيك بيماران مبتلا به اسكيزوفرنيا از افراد مشكوكك قابل استفاده است جرا كه له ضمن ترسيم، به خوبى اختلال در عملكرد ديدارىفضايى اين بيماران را نشان مىدهد و نتايج حاصل از اين فرضيه نيز تأييد كننده دقت بايين افراد مبتلا به اسكيزوفرنيا در ترسيم ساعت بود. اين نتيجه با يافتهاى بـاى

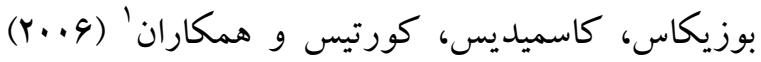
مبنى بر تعداد بالاى خطاهاى بيماران مبتلا به اسكيزوفرنيا در آزمون ترسيم ساعت كاملاً منطبق است. علت وجود

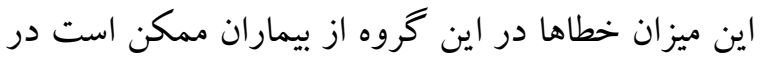

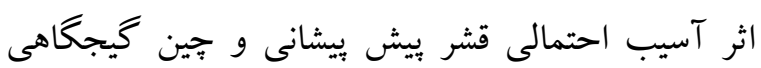

\footnotetext{
${ }^{1}$ - Bozikas, Kosmidis, Kourtis et al\&
} 
مسئولين بيمارستان روانيزشكى مدرس نجف آباد

$$
\text { قدردانى مىشود. }
$$

\section{References}

Alizadeh Safa R, Malmir I. (2015). Comparison of executive functions in schizophrenic patients and normal individuals. Tehran: Annual Conference on New Research Approaches in the Humanities. (In persian)

Altamura C, Fagiolini A, Galderisi S, Rocca P, Rossi A. (2014). Schizophrenia today: epidemiology, diagnosis, course and models of care. Joumal of Psychopathology, 20: 223-243.

Andreasen NC. (2000). A unitary model of schizophrenia: Bleuler's "fragmented phrene" as schizencephaly. Archives of General Psychiatry, 56: 721-7.

Ayano G. (2016). Schizophrenia: A Concise Overview of Etiology, Epidemiology Diagnosis and Management: Review of literatures. Joumal of Schizophrenia Rasearch, 3(2): 1026-1034.

Bhattacharya K. (2015). Cognitive Function in Schizophrenia: A Review. J Psychiatry, 18: 111.

Bozikas VP, Kosmidis MH, Kourtis A, Gamvrula K, Melissidis P, Tsolaki M, Karavatos A. (2006). Clock drawing test in institutionalized patients with schizophrenia compared with Alzheimer's disease patients. Schizophrenia Research, 59: 173-9.

Cangoz B, Karakoc E, Selekler K. (2008). The norm determination and validity-reliability studies of clock drawing test on Turkish adults and elderlys (ages 50 and over). Turkish Joumal of Geriatrics, 9(3): 42-136.

Carrilho CG, Cougo SS, Bombassaro T, Varella AB, Alves GS, Machado S, Murillo-Rodriguez E, Malaspina D, Nardi AE, Veras AB. (2019). Early Trauma and Cognitive Functions of Patients with Schizophrenia. Front Psychiatry, 10:261-269.

Chen J, Yao Z, Qin J, Yan R, Hua L, Lu Q. (2015). Abnormal inter and intra hemispheric integration in male paranoid schizophrenia a

$$
\begin{aligned}
& \text { از جمله محدوديتهاى مهم ئزوهش حاضر، در دسترس } \\
& \text { نبودن ابزار مجزاى مناسب براى بررسى خرخش تصاوير } \\
& \text { بود؛ لذا براى اين منظور از يكى از آيتمهاى آزمون } \\
& \text { بندر گشتالت (جرخش) استفاده شد. بى ترديد در نظر } \\
& \text { كرفتن جامعه آمارى وسيعتر، مىتواند تعميم يذيرى } \\
& \text { بيشتر نتايج را باعث گردد. از محدوديتهاى ديخر اين } \\
& \text { يزووهش وجود تفاوتهاى فردى در شرايط روانى بيماران } \\
& \text { در زمان اجراى آزمونها بود كه ممكن بود سبب كاهش } \\
& \text { دقت باسخدهى آنان گردد. براى رفع اين محدوديت، } \\
& \text { يثزوهشخران سعى كردند درزمانى كه خود بيماران براى }
\end{aligned}
$$

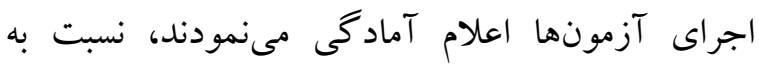

$$
\begin{aligned}
& \text { اجراى آنها اقدام نمايند؛ لذا براى رفع اين محدوديت } \\
& \text { ييشنهاد مىشود در زيزوهشهاى آينده، جهت افزايش } \\
& \text { قدرت تعميميذيرى نتايج بهدستآمده، جامعه آمارى } \\
& \text { وسيعتر با تعداد نمونهاى بيشتر و ملاككهاى ورود } \\
& \text { دقيقتر مورد بررسى قرار گيرند. } \\
& \text { در نهايت با توجه به وجود رابطه بين عملكرد ديدارى- } \\
& \text { فضايى در بيماران اسكيزوفرنيا و بيشبينى عملكردهاى } \\
& \text { اجرايى توسط عملكرد ديدارى-فضايى در آنان، بيشنهاد } \\
& \text { مىشود اين مفاهيم و همجنين روابط بين آنها، به } \\
& \text { متخصصان باز توانى شناختى و توانبخشى شناختى } \\
& \text { بيماران ارائه شود تا اين متخصصان ضمن آشنايى با } \\
& \text { عو امل زمينهاى و مرتبط با نقايص عملكردى در بيماران } \\
& \text { اسكيزوفرنيا، در جهت ارائه درمانهاى شناختى مناسب و } \\
& \text { به موقع براى بيماران خود اقدام نمايند. } \\
& \text { سباسگز ارى }
\end{aligned}
$$

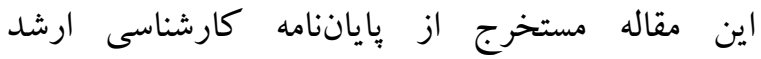

$$
\begin{aligned}
& \text { روانشناسى بالينى دانشگاه آزاد اسلامى واحد نائين است. } \\
& \text { از بيمارانى كه در يثوهش شركت كردند و همجينين }
\end{aligned}
$$


graph theoretical analysis. Shanghai Arch Psychiatry, 25(27):158-166.

Dyck MS, Mathiak KA, Bergert S, Sarkheil P, Koush Y, Alawi EM. (2016). Targeting Treatment Resistant Auditory Verbal Hallucinations in Schizophrenia with fMRI-Based Neurofeedback - Exploring Different Cases of Schizophrenia. Front Psychiatry,7:37-42.

Etkin A, Gyurak A, O'Hara R. (2013). A neurobiological approach to the cognitive deficits of psychiatric disorders. Dialogues Clin Neurosci, 15(4): 419-29.

Farid A, Habibi R, Dadashi S, Bazzaz Monsef F. (2017). The Effect of Neuropsychological Mental Rotation Exercises on Visuospatial Function in Students. Qom Univ Med Sci J, 11 (3), 95-102. (In persian)

Forouzandeh N, Del Aram M, Ain F, Darris F. (2011). The relationship between positive and negative symptoms and quality of life in chronic schizophrenic patients of Sina hospital Juneqan. Joumal of Behavioral Sciences Research, 9(4), 295-304. (In persian)

Ganji K, Asgari M, Torkashvand S. (2011). A Study of Developmental Progression of Clock Face Drawing and Conceptualization of Time in Children. Advances in Cognitive Sciences, 13 (3), 41-54. (In persian)

Ghadiri F, Jazayeri A, A'shayeri H, Ghazi-Tabatabaei M. (2007). The Role of Cognitive Rehabilitation in Reduction of Executive Function Deficits and Obsessive-Compulsive Symptoms in Schizo-Obsessive Patients. Jrehab, 7 (4), 11-24. (In persian)

Ghamari GiviH, Ghasem Nejad S. (2008). The Role of Clock Drawing Test in Evaluation of Cortical Disorder in Schizophrenia. J Ardabil Univ Med Sci, 8 (3), 301-308. (In persian)

Goodarzi MA, Khosravani N, Tarikhi AR. (2011). Comparison of the performance of patients with schizophrenia and normal individuals in the contrast sensitivity test. Joumal of Cognitive Sciences, 13 (3), 75-82. (In persian)

Holmen A. (2012). Executive function in early- and adult onset schizophrenia. Schizophrenia Research, 320(3): 355-330.
Hooman HA, Ganji K, Faraj Elahi R. (2011). Evaluation of capability, validity and reliability of watch drawing test (CDT) in primary school children in Tehran. Educational Measurement Quarterly, 2 (2), 137-161. (In persian)

Javanmard GhH. (2015). The study of executive functions of schizophrenic patients' with negative and positive symptoms and healthy people's by using Wisconsin Card Sorting Test (WCST). Joumal of Neuropsychology is a scientific, 1(1), 7-16. (In persian)

Kraguljac NV, Srivastava A, Lahti AC. (2013). Memory deficits in schizophrenia: a selective review of functional magnetic resonance imaging (FMRI) studies. Behavioral Sci, 3(3): 330-347.

Kumar R. (2016). Cognitive Insight and Executive Function in Schizophrenia Kiran Srivastava and Rakesh Kumar. SIS J. Proj. Psy \& Ment. Health, (23): 106-114.

Kumar S, SharmaVD, Mohanty S, Kumar R. (2004). A Compersion of Human Figure Drawing Among Schizophrenics, Manics and Contral Groups. SIS J. Proj. Psy \& ment. Health, 11: 47-51.

Levenson JL, Collins J, Puram D. (2005). Images in psychosomatic medicine: The ClockDrawing Test. Psychosomatics, 46: 77-8.

Lieberman JA, Murray RM, Tonia T. (2010). Comprehensive care of schizophrenia. Oxford University Press.

Martinez A, Hillyard SA, Dias EC, Hagler DJJr, Butler PD, Guilfoyle DN. (2008). Magnocellular pathway impairment in schizophrenia: Evidence from functional magnetic resonance imaging. Joumal of Neuroscience, 28: 74927500 .

Matthewsa LM, Collinsb KP, Thakkar NT, Park S. (2015). Visuo-spatial imagery and working memory in schizophreni. Cognitive Neuropsychiatry, 19(1): 17-35.

Molloy DW, Alemayehu E, Roberts R. (1991). Reliability of a Standardized Mini-Mental State Examination compared with the 
traditional Mini-Mental State Examination. Am J Psychiatry, 148(1):102-5.

Musa Zadegan S, Marofi M. (2016). Comparison of executive functions between different phases in patients with type 1 bipolar disorder and normal individuals. Journal of Isfahan School of Medicine, 35 (462), 1892-1901. (In persian)

Nakamura H, Watanabe N, Matsushima E. (2014). Structural equation model of factors related to quality of life for community-dwelling schizophrenic patients in Japan. Int J Mental Health Systems, 8(1): 32-41.

Neill E, Rossell S. (2013). Executive functioning in schizophrenia: The result of impairments in lower order cognitive skills?, Schizophrenia Research, 333(3): 52-33.

Pantelis C, Wood SJ, Manuff P. (2002). In Harrion JE, Owen A M. (Eds.). Cognitive deficit in brain disorders. Martin Dunitz: London.

Rajii TK, Mulsant BH. (2011). Nature and course of cognitive function in late-life schizophrenia: a systematic review. Schizophrenia Research, 102(1-3): 122-140.

Ransing RS, Khairkar PH, Mishra K. (2018). Potential Bedside Utility of the Clock-Drawing Test in Evaluating Rapid Therapeutic Response in the Natural Course of Schizophrenia: A Preliminary Study. J Neuropsychiatry Clin Neurosci, 29:289-292.

Schramm U, Berger G, Muller R, Kratzsch T, Peters J, Frolich L. (2002). Psychometric properties of Clock Drawing Test and MMSE or Short Performance Test (SKT) in dementia screening in a memory population. International Joumal of Geriatric Psychiatry, 17(3): 245-260.

Shafiei E, Fakharian E, Omidi A, Akbari H, Delpisheh A. (2017). Visual Spatial Working Memory in Patients with Mild Brain Injury Using Benton Visual Retention Test: A Prospective Cohort Study. J Mazandaran Univ Med Sci, 26 (144), 314-323. (In persian)

Shulman K, Feinstein A. (2003). Quick cognitive screening for clinicians: Mini Mental, Clock Drawing and other brief tests. London: Martin Donitz.
Sidian M, Fallah M, Nowruzian M, Nejat S, Delavar AS, Ghasemzadeh HA. (2007). Determining and validating the Persian version of the Quatt test of mental state. Scientific Journal of the Medical System Organization of the Islamic Republic of Iran, 25 (4), 408-414. (In persian)

Srivastava K, Kumar R. (2016). Cognitive Insight and Executive Function in Schizophrenia. SIS J. Proj.Psy \& Ment. Health, 23: 106-114.

Taghizadeh H, Soltani A, Manzari Tavakoli HA, Zainuddin Meymand Z (2016). Executive functions of visual-spatial working memory and inhibition of response in the performance of mental abilities of mind theory in children 7 to 12 years of primary school. Two Quarterly Joumal of Social Research, 6 (4), 136-153. (In persian)

Varaei AA, Rashidipour A, Bouresh j. (2003). Assessment the Role of the Orbitofrontal Cortex on Spatial Memory in Dark and Light Area to Place Avoidance Learning in a Rat. Research in Medicine. 2003; 27 (3), 225-231. (In persian) 